\title{
From the Philosophy of Nature to a New Materialist Politics
}

One of the most important moments of today's theory is a closer interaction of the humanities, social, and natural sciences against a backdrop of the extensively proclaimed materialist turn. Philosophy brings a new agenda to this dialogue of sciences and disciplines, one that attempts to bridge the gap between scientific ontology and philosophical epistemology. The bridging of this gap brings together recent investigations in science and technology with a rethinking of historical process from the nonhuman perspective: the history of humankind must be brought into correlation with the history of things, and world history with the history of the earth. The classical concept of nature, whose criticism stems from its being rooted in the idealist tradition characterized by a system of opposites and general anthropocentric presumptions, is now subject to serious discussions: perhaps, in the contemporary context, it is more expedient to speak of geophilosophy as a point of contention of various kinds of materialisms.

The term "geophilosophy" is borrowed from Gilles Deleuze and Félix Guattari, who introduced it to designate a spatial model of immanent thinking through the correlation between the territory and the earth, which would situate philosophy between political economy, anthropology, geography, but also earth sciences and the like. Within this correlation, nonhuman forms of living and inanimate matter are included in the historical process that is no longer conceived as a sequence of stages in the development of human societies, but as a series of geological epochs. Originally coming from ecology and atmospheric chemistry, the term "Anthropocene" has transformed into a powerful interdisciplinary concept challenged by various alternatives from the Novacene to the Capitalocene, Plantationocene, Chthulucene, and others.

In geophilosophy, economy collides with ecology, which provides the condition to reflect upon a kind of planetary politics - planetary not so much in the sense of the global, or international, as rather in the sense of an interspecies one. Moreover, what is at stake is politics at the level of the biosphere, the noosphere or the technosphere, which all earthly beings and matter are involved in: animals, plants, 
humans, mountains, sounds, viruses, artificial intelligence, and so on. The materialist turn prompts a rethinking of political participation in terms of nonhuman collectives, parliaments of things, democracies of objects, ontological diplomacies, solidarity with nonhuman peoples, eco-justice, and so on.

The urgency of a geophilosophical reconceptualization is provoked by the reality of climate change. It is not that this reality had not been there before: the dangers of the greenhouse effect reinforced by carbon emissions and other factors of industrial developments were already indicated by scientists in the 1960s. But only recently have they started to be taken seriously by the general public, and even by governments and corporations. The discourse of the Anthropocene, proclaiming a new geological era marked by the intervention of human technologies that have visibly destabilized planetary life, is a critical one: what we call progress is nothing but the destruction of the biosphere, of the environment that we share with all other earthly things. Nonetheless, the flipside of this criticism is a paradoxical arrogance that implies the omnipotence of humans: Why do we destroy nature? - Because we can! Is it not that, in this aspect, the idea of the Anthropocene is itself anthropocentric? In 2020, however, this arrogance is taken down by an infinitesimal nonhuman thing that is not even properly alive. Out of human view, the virus wavers between life and death. Its way of replication is such that it breaks the existence of our communities and endangers all our infrastructures and socioeconomic systems. The pandemic teaches us that we are not that powerful and that there are still those natural forces that we cannot control. Moreover, the situation proves that the natural and the social is not an opposition, but a concrete unity. Climate change, pandemic, and social collapse that now results in the spontaneous uprisings not only in the US, but in various places around the globe, create a processual composition that cannot be grasped by separate positive sciences, but demands a syncretic geophilosophical approach: we must find the roots of these phenomena that are not so obvious and can actually be traced back to such different things as the extractive economy treating Earth and nature as profitable resources, colonialism treating peoples and territories as profitable resources, and capitalism treating everything as profitable resources. It traces back from economy and politics to our cosmologies, to myths and anthropological invariants, to the structures or consciousness, and the unconscious structures of humans and nonhumans.

Albeit based on a radical critique of the classical philosophy of nature, New Materialist approaches do not, however, cancel it out 
(some authors try to do that, indeed, but, in their Oedipal frenzy, they remain blind to the fact that they simply bite the hand that feeds them). On the contrary, one of the most distinctive recent trends is the return of the philosophy of nature, which acquires new meanings in the course of its critical re-evaluation and reveals the possibility of alternative progressive readings. There are non-trivial connections and parallels found between the new materialisms and the philosophy of nature - from the atomism of Democritus and Epicurus or Lucretius, the natural philosophy of Schelling, and Hegel's philosophy of nature, to the new materialism of Marx, calling for a shift from the criticism of heaven to the criticism of Earth. In this intellectual exchange between historical and recent concepts, new political theories arise or old ones - theories of the republic, democracy, or communism - are transformed. Such connections and parallels are the main topic of this special issue.

Oxana Timofeeva 